口絵 1 : 宮崎平野に分布するテフラから推定される過去 60 万年間の霧島火山の爆発的噴火史

\title{
Pictorial 1 : The Past 600 ka Explosive Eruptive History of Kirishima Volcano in Southern Japan
}

南九州の宮崎平野には多数の第四紀テフラが分布し，段丘堆積物などの対比や火山活動史の編年に使用されてきた. 10 万年前以降 のテフラについては従来から多くの知見が得られていたが，それ以前のテフラについては層序や対比が混乱していた。今回，10万〜 100 万年前のテフラ層序・年代が確立され，それとともに 60 万年間の霧島火山の活動が明らかにされた. 詳しくは長岡ほか $(2010)$ 参照.

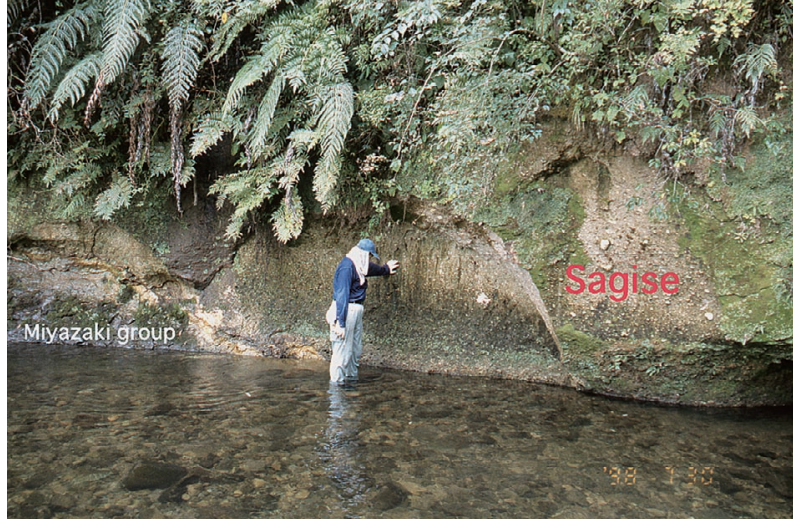

図 1 田野町井倉川沿い A1 地点の鷺瀬火砕流堆積物. 鷺瀬火 砕流堆積物は，宮崎平野において宮崎層群を除く陸成第 四系最下部，仮屋層基底にあって，フィショントラック 年代で $1 \mathrm{Ma}$ 〜 $800 \mathrm{ka}$ を示す.

Fig. 1 Sagise pyroclastic flow deposit at A1 site, Ikura river in Tano town. Sagise pyroclastic flow deposit at the bottom of the Kariya formation, which formed in fluvial and lacustrine environments, is $1 \mathrm{Ma}$ to $800 \mathrm{ka}$ old and one of the oldest tephras in the non-marine Quaternary sediments.

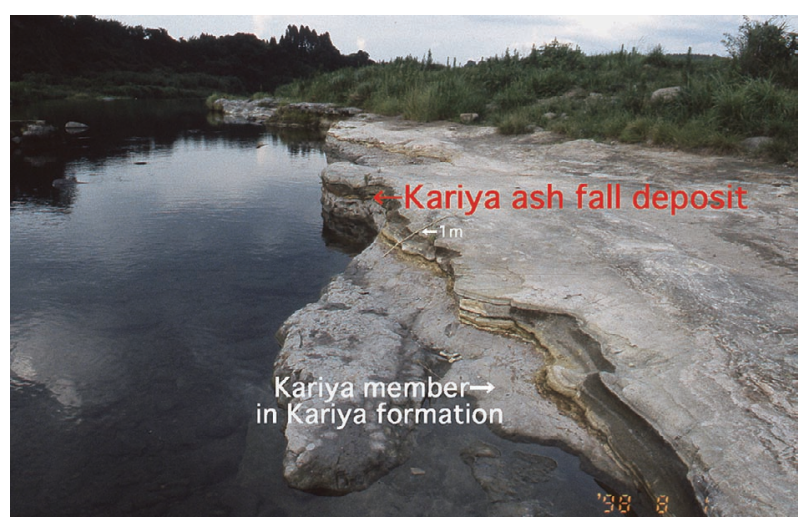

図 2 田野町仮屋 A4 地点の仮屋降下火山灰層. 仮屋降下火山 灰層は, 鷺瀬火砕流堆積物上位, 仮屋層中部にあって, フィッション・トラック年代で約 $800 \mathrm{ka}$ を示す.

Fig. 2 Kariya ash fall deposit at A4 site, Kariya in Tano town. The Kariya ash fall deposit in the middle of the Kariya formation is $800 \mathrm{ka}$ old.

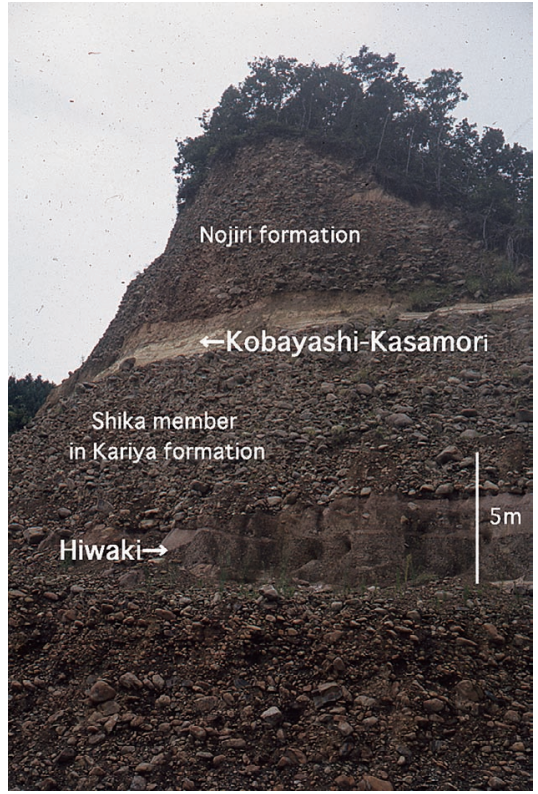

図 3 綾町上畑の採石場 B9 地点の樋脇火砕流堆積物と小林笠 森降下軽石・灭砕流堆積物. $600 \mathrm{ka}$ の樋脇火砕流堆積 物は仮屋層上部の磁層に含まれている。 その上位で，野 尻層基底にある小林笠森降下軽石層は, 約 $500 \mathrm{ka}$ の小 林笠森火砕流堆積物に先立つテフラである.

Fig. 3 Hiwaki pyroclastic flow deposit and KobayashiKasamori pumice fall deposit at B9 site, Kamihata in Aya town. 600 ka-old Hiwaki pyroclastic flow deposit is interbedded in the upper part of the Kariya formation. 500 ka-old Kobayashi-Kasamori pumice fall and pyroclastic flow deposits overlie the bottom of the Nojiri formation, fluvial gravel sediment in the photo.

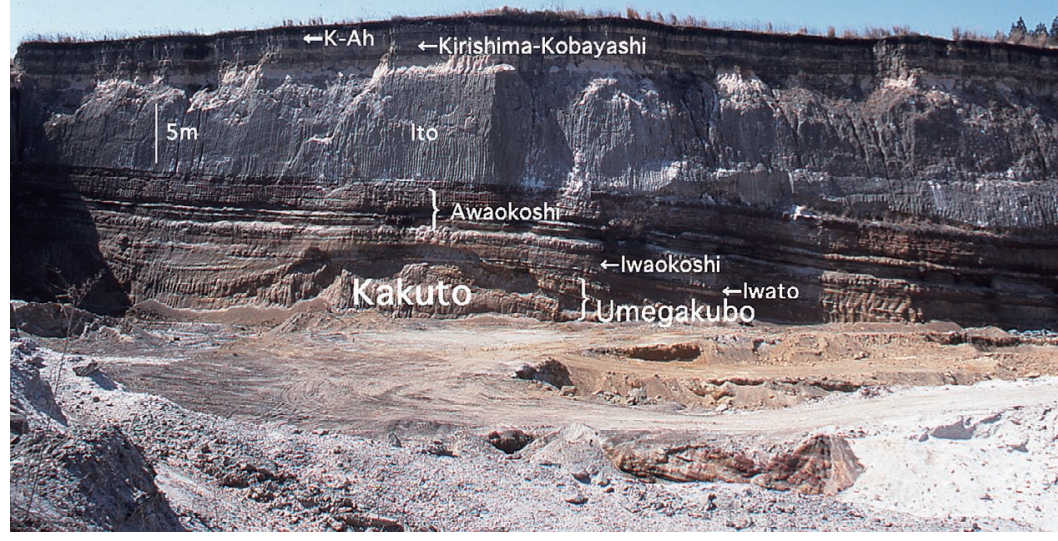

図 4 高原町梅ヶ久保 B1 地点の中期更新世の加久藤火砕 流堆積物，梅ヶ久保降下テフラ群と，それを不整合 に覆う岩戸・アワオコシ・イワオコシ・入戸・霧島 小林・鬼界アカホヤ（K-Ah）などの後期更新世〜完 新世テフラ. 約 $330 \mathrm{ka}$ の加久藤火砕流堆積物で以て, カルデラ形成を特徴とする古期霧島火山の活動は終 わる。この火砕流堆積物は大きな不整合を伴わずに 梅ヶ久保降下軽石・テフラ群に覆われる.

Fig. 4 At B1 site, Umegakubo in Takaharu town, Kakuto pyroclastic flow deposit and Umegakubo tephra fall deposits underlie the late Pleistocene to Holocene tephra layers: Iwato, Awaokoshi, Iwaokoshi, Ito, Kirishima-Kobayashi, and K-Ah. 
ロ絵 1 (つづき)：宮崎平野に分布するテフラから推定される過去 60 万年間の霧島火山の爆発的噴火史

\section{Pictorial 1 : The Past 600 ka Explosive Eruptive History of Kirishima Volcano in Southern Japan}

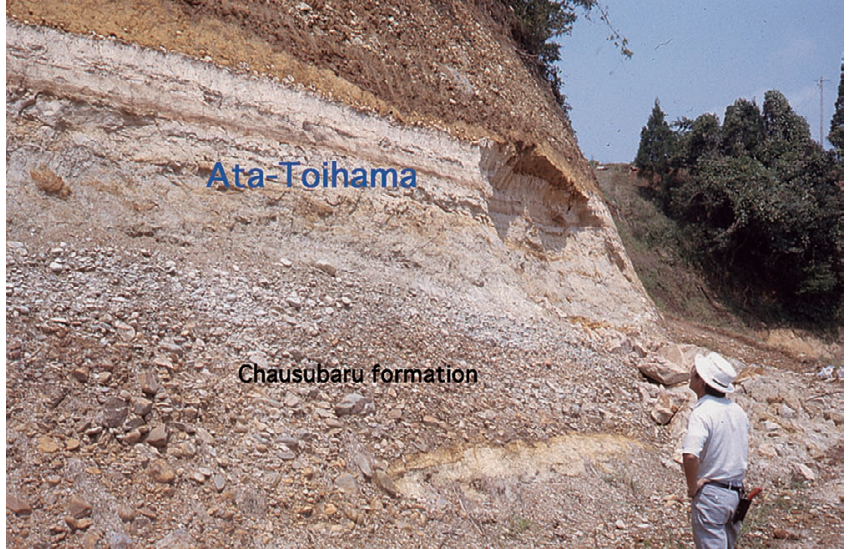

図 5 綾町尾立 D4 地点の茶臼原段丘堆積物中の阿多鳥浜火 砕流堆積物. 阿多カルデラ起源の約 $240 \mathrm{ka}$ の阿多鳥 浜火砕流堆積物は, 宮崎平野に広く薄く分布する特異 な火砕流堆積物である.

Fig. 5 Ata-Toihama pyroclastic flow deposit in Chausubaru fluvial gravel formation at D4 site, Odate in Aya town. Ata-Toihama pyroclastic flow deposit is a kind of low aspect ratio ignmbrite.

図 6 田野町元野 T5 地点で, 新田原段丘堆積物と関係する 阿多火砕流堆積物，鬼界葛原降下火山灰層（K-Tz）, 福山降下軽石堆積物，岩戸降下軽石堆積物，姶良 Tn 降下火山灰 (AT), 鬼界アカホヤ降下火山灰 (K-Ah).

Fig. 6 Ata pyroclastic flow, Kikai-Tozurahara ash fall deposit (K-Tz), Fukuyama pumice fall deposit, Iwato pumice fall deposit, Aira-Tn ash fall deposit (AT), Kikai-Akahoya ash fall deposit (K-Ah) interbedded in or covering Nyutabaru formation of fluvial terrace deposit at T5, Motono in Tano town.
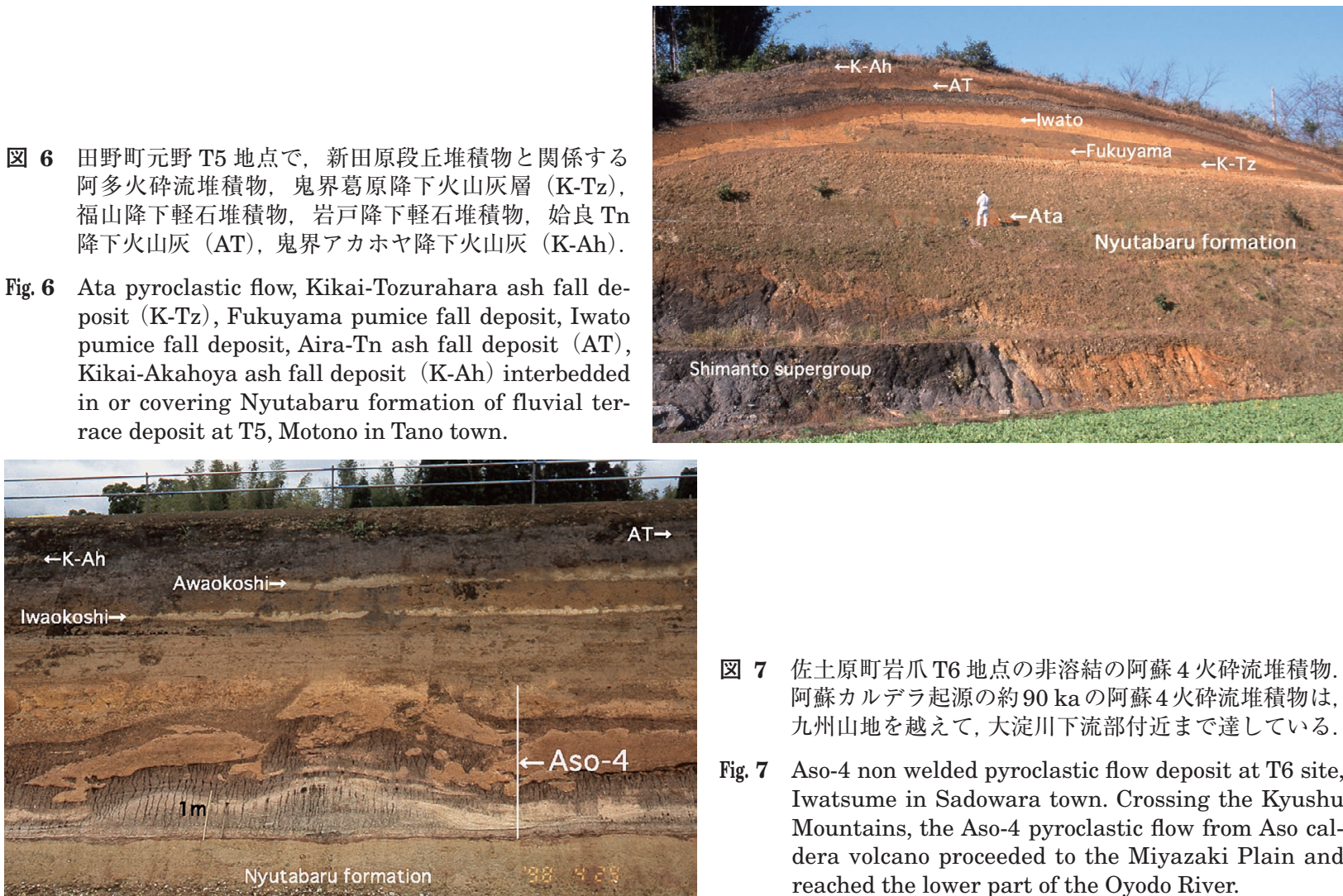

図 7 佐土原町岩爪 T6 地点の非溶結の阿蘇 4 火砕流堆積物。 阿蘇カルデラ起源の約 $90 \mathrm{ka}$ の阿蘇 4 火砕流堆積物は, 九州山地を越えて, 大淀川下流部付近まで達している.

Fig. 7 Aso-4 non welded pyroclastic flow deposit at T6 site, Iwatsume in Sadowara town. Crossing the Kyushu Mountains, the Aso-4 pyroclastic flow from Aso caldera volcano proceeded to the Miyazaki Plain and reached the lower part of the Oyodo River.

図 8 高原町梅ヶ久保 B1 地点で入戸火砕流堆積物などに覆 われるイワオコシ降下軽石堆積物とアワオコシ降下ス コリア堆積物. 大浪池起源のイワオコシ降下軽石堆 積物, 夷守岳起源のアワオコシ降下スコリア堆積物 は，新期霧島火山の Y 3 ステージ（50〜30 ka）に 属する。

Fig. 8 Iwaokoshi pumice fall deposit and Awaokoshi scoria fall deposit overlaid by Ito pyroclastic flow deposit at B1 site, Umegakubo in Takaharu town. Y3 stage, 50-30 ka old, in Younger Kirishima volcano includes Iwaokoshi pumice fall deposit from Onaminoike volcano and Awaokoshi scoria fall deposit from $\mathrm{Hi}$ namori volcano.

長岡信治・新井房夫・檀原 徹 (2009): 宮崎平野に分布するテフラ から推定される過去 60 万年間の霧島火山の爆発的噴火史. 地学雑誌, 119, 121-152.

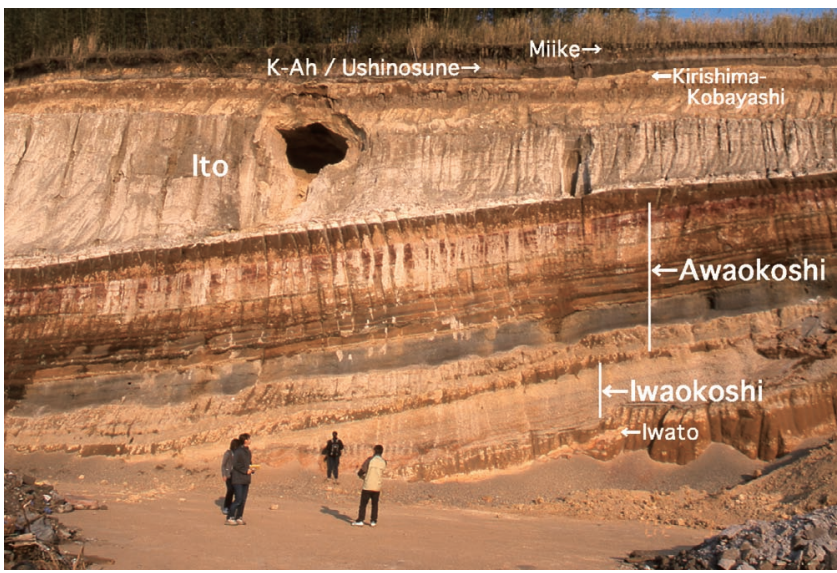

(長岡信治・新井戻夫・檀原 徹)

(Shinji NAGAOKA, Fusao ARAI and Tohru DANHARA) 